\title{
Code-switching and translated/untranslated repetitions in Nuyorican Spanglish
}

\author{
Marina Semenova* \\ Don State Technical University, 344000, Rostov-on-Don, Russia
}

\begin{abstract}
Nuyorican Spanglish is a variety of Spanglish used primarily by people of Puerto Rican origin living in New York. Like many other varieties of the hybrid Spanglish idiom, it is based on extensive codeswitching. The objective of the article is to discuss the main features of code-switching as a strategy in Nuyrican Spanglish applying the methods of linguistic, componential, distribution and statistical analysis. The paper focuses on prosiac and poetic texts created in Nuyrican Spanglish between 1978 and 2020, including the novel Yo-Yo Boing! by Giannina Braschi and 142 selected Boricua poems, which allows us to make certain observations on the philosophy and identity of Nuyorican Spanglish speakers. As a result, two types of code-switching as a strategy are denoted: external and internal code-switching for both written and oral speech forms. Further, it is concluded that repetition, also falling into two categories (translated and untranslated), embodies the core values of Nuyorican Spanglish (freedom of choice and focus on the linguistic personality) and reflects the philosophical basis for code-switching.
\end{abstract}

\section{Introduction}

Nuyorican Spanglish is a Spanglish dialect used in New York's East Side primarily by people of Puerto Rican origin, many of who are first- or second-generation New Yorkers. This means that Spanglish they use is rather the most effective way to communicate between English and Spanish cultures which come into an extremely intense contact in this cosmopolitan city.

There have been academic publications tackling code-switching in a generalized category of theoretical grammar [1]. Sometimes such approaches can lead to interpreting code-switching as a monolingual strategy likening it to the process of borrowing [2]. This approach is especially popular among British linguists and is based on the idea of English being the only dominating international lingua franca of modern times [3].

A wide range of academic papers have approached the study of Spanglish as a mixed language [4, 5]. Among them, special attention is given to language policies [6, 7], segregation issues [8], sociolinguistic and socio-pragmatic aspects [9-11].

As compared to the above, fewer papers focus on the issue of code-switching patterns in Spanglish in general $[6,12,13]$. They show and prove the most wide-spread codeswitching patterns that can be witnessed in all varieties of Spanglish:

*Corresponding author: mosap-spo@yandex.ru 
1. Between the main part of the sentence and the complicating elements (an introductory word, address or interjection), e. g.: This is a pretty interesting subject, verdad? No way! No tengo carga, honey. Yeah, pero quedó supercool.

2. Before an adjective or participle in a predicative function, e. g.: Mi marido está working on his Master's. I am not puertorriqueña.

3. Between the parts of a complex sentence, e. g.: Buy your home in Levittown Lakes, donde la buena vida comienza. Yo y mi Winston - porque Winstons taste good like a cigarette should.

4. Between an article (or a demonstrative pronoun) and a noun, if the form of the article is an analytical gender indicator for a noun that does not have corresponding synthetic markers, e. g.: Voy al shopping center. Se me perdió el lipstick.

5. Before an advervial modifier, e. g.: Hágalo anyway. Vas al coffee break ahora.

These studies also prove that code-switching does not occur in certain cases:

1. Between the clitics (i. e., a grammatically independent but phonetically dependent unstressed form of the pronoun) and the word with which it is associated; apparently, this is due to different features of the use of forms of personal pronouns in indirect cases in English and Spanish, as well as different word order in syntagms containing such forms, e. g.: She puts him breakfast to Alex on the couch! Put him the juice. (*She le puts breakfast to Alex on the couch! and * Le put the juice are not possible.)

2. Between the subject expressed by a Spanish personal pronoun, and the predicate, which is due to the fact that the presence of a subject is mandatory in English, while in Spanish such subjects are omitted in most cases since finite verb forms denote the person and the number, e. g.: Ella tiene ojos braun. ( ${ }^{*}$ She tiene ojos braun is not possible.)

Spanglish is characterized by sufficient stability of structures and its own phonological system, which is confirmed in [3], showing that such structural consistency promotes the spread of Spanglish among people who do not speak either English or Spanish.

Spanglish and, more specifically, its code-switching strategies together with the accompanying linguistic phenomena represent an important and pressing issue in modern linguistics as this idiom is considered to possess the necessary criteria to be classified an independent language:

1) the presence of a standardized and recognizable phonological system passed down from generation to generation;

2) the presence of certain lexical and phraseological elements inherent in this idiom and describing key concepts;

3) the existing community of Spanglish speakers, who use, develop, and stabilize it;

4) the presence of texts of different functional styles (in particular, fiction) in Spanglish;

5) the presence of dictionaries and other databases that track and regulate the use of this idiom, as well as contribute to the self-identification of its carriers.

Nevertheless, the dialects of Spanglish have almost never been a focus of academic literature. Quite a few papers deal with a deeper insight into systematizing the features of any of Spanglish varieties. Even doing so, they are interested in describing individual varieties of Spanglish as a group, usually big enough to treat Nuyorican and Caribbean varieties of Spanglish as one idiom $[6,11]$.

So, the objective of this article is to concentrate on code-switching strategy of Nuyorican Spanglish that are observed in the oral and written speech as external and internal code-switching. Another important issue to study code-switching based on translated and untranslated repetitions. This code-switching type is particularly popular among Nuyoricans and provides a basis for the extensive play of words, especially in literary texts, under the obvious influence of the hip-hop and rap cultures. Finally the paper aims at giving a cross-cutting overview of language philosophy that stands behind the 
analyzed linguistic phenomenon and exploits the idea of duplicating cultures and identities through the duplicated language code.

\section{Materials and Methods}

The study is based on literary texts, both prosaic and poetic, created in the oral and written forms of Nuyorican Spanglish, which include the following:

1. Experimental novel Yo-Yo Boing! by the New York writer and literary critic of Puerto Rican origin Giannina Braschi published in 1998.

2. 142 selected poems available online in the open sources and published between 1978 and 2020 by the following Boricua poets: Giannina Braschi, Victor Hernández Cruz, Magdalena Gómez, María Aponte, Carmen Barduguez-Brown, Caridad De La Luz a.k.a. LA BRUJA, Marina Ortiz, J. F. SEARY, Noel Quiñones, Ivanna, and Judy Vásquez. Out of 142, 63 poems are presented in the form of the oral speech, and 79 poems are in the form of the written speech.

The main features of code-switching and repetition in Nuyorican Spanglish are studied applying the methods of linguistic, componential, distribution and statistical analysis.

Linguistic analysis based on comparison and contrast is necessary to find and define Nuyorican Spanglish translingual elements by analyzing the phonemic and/or graphic composition, lexical meaning and morphology of these elements to differentiate them from purely English or Spanish elements deprived of translingual contamination.

Componential analysis is used to extract principal and verifiable code-switching and repetition patterns basing on semantic and cultural description.

Distribution analysis as a particular form of structural analysis is a method to evaluate the frequency of given code-switches and repetitions in the gathered Nuyorican Spanglish material. It is also helpful to denote the position which Nuyorican Spanglish units occupy or may occupy in the text.

Statistical analysis aims at classifying the cases of code-switching in terms of their frequency thus establishing the correlation between external and internal code-switching in the oral and written speech.

\section{Results}

\subsection{External and internal code-switching in Nuyorican Spanglish}

As one of the most important criteria to distinguish a language is the universality and stability of its units at various levels, it seems critical to prove that observed code-switching cases possess the above-mentioned characteristics. For this purpose, code-switching can be categorized as external (i. e., occurring between sentences and/or paragraphs) and internal (i. e., occurring within sentences: between clauses, words, morphemes or phonemes/graphemes). This classification rests on the idea that is based on two mutually exclusive and collectively exhaustive assumptions:

1. If Spanglish is a Creole language, its speakers are not fluent enough in both substrate languages, so code-switching occurs mainly between separate sentences or paragraphs. It is unlikely to take place at a lower level because the speaker is not aware of the normative compatibility in the overlapping grammars, lexical and semantic structures, phonological systems.

2. If Spanglish is a mixed language of a new type, its speakers will be well aware of various limitations in transforming structures of substrate languages into a new hybrid. This will allow them to switch the code at all language levels, including within a sentence. 
The data gathered in the literary texts in Nuyorican Spanglish were classified into external and internal code-switching cases in the oral and written speech, which makes it possible to apply statistical comparison to find out which assumption above is true for Nuyorican Spanglish, and whether it is possible to prove the stability and sustainability of Nuyorican Spanglish by a regular distribution of code-switching in the oral and written speech across a wide range of texts.

Also, the results obtained in this paper (see Table 1) are correlated with those achieved by the American linguist C. Montes-Alcalá who studied code-switching in Nuyorican and Cuban American Spanglish [11].

Table 1. Statistical comparison of external and internal code-switching G. Braschi's Yo-Yo Boing! with other studies

\begin{tabular}{|l|c|c|c|}
\hline $\begin{array}{c}\text { Code-switching } \\
\text { type }\end{array}$ & $\begin{array}{c}\text { Yo-Yo Boing! } \\
\text { by G. Braschi }\end{array}$ & $\begin{array}{c}142 \text { selected } \\
\text { Boricua poems }\end{array}$ & $\begin{array}{c}\text { Study } \\
\text { by C. Montes- } \\
\text { Alcalá }\end{array}$ \\
\hline $\begin{array}{l}\text { External } \\
\text { code-switching }\end{array}$ & $\begin{array}{c}\text { Written speech: } \\
29 \%\end{array}$ & $\begin{array}{c}\text { Oral speech: } 35 \% \\
\text { Written speech: } \\
20 \%\end{array}$ & $\begin{array}{c}\text { Oral speech: } 53 \% \\
\text { Written speech: } \\
30 \%\end{array}$ \\
\hline $\begin{array}{l}\text { Internal } \\
\text { code-switching }\end{array}$ & $\begin{array}{c}\text { Written speech: } \\
71 \%\end{array}$ & $\begin{array}{c}\text { Wral speech: } 65 \% \\
\text { Written speech: } \\
80 \%\end{array}$ & $\begin{array}{c}\text { Oral speech: } 47 \% \\
\text { Written speech: } \\
70 \%\end{array}$ \\
\hline
\end{tabular}

Table 1 shows a considerable degree of correlation across the analyzed Nuyorican Spanglish texts as well as with the study by C. Montes-Alcalá, especially in the proportions of external and internal code-switching in the written speech. It is a vivid confirmation of the second point supporting the idea that Spanglish functions as a fully consistent language system which denotes the unique ethnic and cultural identity of its speakers. Codeswitching for Spanglish speakers is a way to state their belonged to both monolingual worlds: a prestigious English world and a stigmatized Spanish. These people have no other choice than to switch between the two worlds unwilling to give up either of them because that would mean being on the perifery as a discriminated minority [14].

However, code-switching distribution in the oral speech demonstrates less correlation, with the internal type being more characteristic of Nuyorican Spanglish. The tendency can be explained by the fact that C. Montes-Alcalá also includes Cuban Spanglish in the scope of her academic attention, where English fluency is, for many social, economic and political reasons, not so obvious as in Nuyorican Spanglish. This, in turns, crated technical obstacles and imposes limitations for internal code-switching, particularly in the oral speech, which is more spontaneous and features easy-to-use speech patterns. Another reason might be the connection between Spanglish and digital communication technologies that facilitate its development and distribution [15] involving more people in the Spanglish social interaction process, which might also be dependent on the level of their cultural and linguistic awareness.

\subsection{Repetitions as a code-switching strategy in Nuyorican Spanglish}

Repetitions turn to be quite a popular code-switching strategy in Nuyorican Spanglish, which might be well explained by the influence of hip-hop and rap cultures in which many Spanglish speakers are involved both as regular participants and as mainstream leaders. It gives Nuyorican the possibility to remix language elements in the same way in which music fragments are remixed to create a new piece, e. g.:

(1) ruh-ruh-ruh-remixed, porque no me gusta shit that ain't new 
(2) We repetitious accent, heard ya Collard Green rhyme Spittin' DO DO DO after playin' accent part time

How many rappers gunna take this tongue out for a ride?

This strategy is an inherent element of any variety of Spanglish being the materialization of the idea of duplicated language and cultural codes that creates such a hybrid idiom. Repetition serves the echo function throwing the light on the contradictions and conflicts that torture Spanglish speakers living between two cultures and two languages, e. g.:

(3) - Si tú dices: Nunca. Oíste. No estoy enamorada. Yo soy un eco. Y el eco responde: Estoy enamorada. Estoy enamorada. Te amo. Te amo.

- It's torture to have to hear the opposite of what I negate. I say: I don't love you.

- I say: Love you. Love you.

- It breaks a person spirit. Don't you think?

- You think. You think.

— So I always have to hear your back-talk.

- It's your own voice contradicting you.

- No estoy enamorada.

— Estoy enamorada. Estoy enamorada. Te amo. Te amo.

- It's true. Eco is original.

Repetitions in Nuyorican Spanglish code-switching fall into two big categories: translated and untranslated repetitions. The first one means that the units used in one substrate language are then translated into the other subsrate language, which leads to the full duplication of code. In the second case, repetitions are used in one substrate language only and serve other functions: they are not to simply transplant the code, they are to embody the philosophy of duplicated identity and to create a dynamic rhythmical structure that attracts attention and turns every speech fragment in a powerful public performance. Interestingly, the use of stylistic devices and rhethoric canons make the readers compare them to the greatest speeches of those fighting for human rights and protesting againt segregation, like Dr. Martin Luther King, Jr.

The importance of the second category makes it a more frequent device amounting to $80 \%$ of all cases. Another critical observation is that translated repetitions cannot be further subdivided into types, while untranslated repetitions demonstrate a wide variety of forms, which you can see below.

1. Translated repetitions:

(4) - I want my orange juice. Juicy red with its pepas.

- Seeds.

(5) - ¿Y por qué no agua?

— No agua.

- Why not agua, agua?

(6) Frenillo. Ponle freno a tus escribos.

Hold your horses - frena los caballos -

Hold your horses - relinchan los caballos -

Hold your horses - Whuiiiiii. Stop.

2. Untranslated repetitions:

a) duplication/triplication of nouns and verb forms:

(7) - Tess, Tess.

- Just a moment, Makiko.

- What about the composition.

— Look, Tess, look.

- Fire, Mona, fire.

- El mantel is burning, burning, burning. 
- Agua, agua.

— No agua. Use napkins. No agua.

b) duplication/triplication of interjections:

(8) Ouch! Ounch!

(9) Tirirí. Tirirí. Tirirí.

Tirirí. Tirirí. Tirirí.

Necesitaba ejercitar los dedos de mis manos. Sobre todo el meñique.

Rí. Rí. Rí.

(10) - Hoy tengo que salir — decía Jabalí - Ahem. Department greetings. Ahem. Tú comprenderás. Ahem. No puedes venir conmigo. Ahem. Son profesores.

c) anaphoric repetitions:

(11) Cuando yo no aguanto más. Cuando no quiero. Lo hago. Cuando no tengo ganas. Cuando me estoy riendo. Cuando no sale el sol. Cuando no lo quiero hacer. Cuando sé lo que tengo que hacer. Cuando estoy solo. Cuando me siento mal. Cuando está lloviendo. Y se seca. Cuando no puedo más. Cuando quiero.

(12) English mouth sips.

Spanish mouth swallows.

Spanish mouth is not afraid of cicharrones;

English mouth takes Lipitor and fears liver disease.

d) epiphoric repetitions:

(13) $\quad-<\ldots>$ I said - She's writing a screen play.

- A screen play! — he said.

d) dilemma repetitions:

(14) - Lo saludo o no lo saludo. Vírale la cara. No la vires la cara. Sí, hazlo.

e) full sentences:

(15) Mírame, linda. Mírame, linda.

f) syntactical structures:

(16) My whole party ruined. My whole table burned.

(17) Let her talk. Sure, and if if she had a gun, you'd say: Let her shoot.

Repetitions as a code-switching strategy can trigger play of words which can intensify the dualism that a Nuyorican Spanglish speaker faces in real life. Examples (14) and (15) play around the idea of vulgarity, aggression violence of the English-speaking world:

(18) - Llueve, llueve, y me mojo.

Listen $<\ldots>$

—Vue-lo. Vue-e-elo — she thumbed over her shoulder — Follow the music.

- You were fantastic. I loved when you gave the vuelos the e-e-elos. You were the only one who understood $<$...>

- What a lack of respect - you murmured -yelling vulgarities.

(19) Macbeth has murdered sleep. I can't remember my lines. My hands are bloody sleepy, bloody merry, bloody mary, with scotch on the rocks and my heart just stands still for Al Pacino.

\section{Discussion}

The philosophical concept of a linguistic experiment related to code-switching is essentially a manifesto of Nuyorican Spanglish speakers in the United States, since the key function of Spanglish in general and its Nuyorican variety in particular is to mark the ethnic and cultural identity of its speakers. Compared to standard languages, Spanglish holds a better position as code-switching gives its speakers the ability to belong to both cultures without having to choose between them. G. Braschi's novel and Boricua poetry is an excellent illustration of this thesis. Nuyorican Spanglish writers and poets deliberately and 
voluntarily refuse this choice. Their Spanglish is not a compromise or a borderline state, it is a self-contained idiom that emphasizes the ideas of freedom, variability and dialogue between cultures. At the same time, these writers demonstrate mastery of Spanish and English, which proves once again that Spanglish cannot be regarded as the language of illiterate Puerto Ricans who immigrated to New York.

The philosophy of Nuyorican Spanglish has two main constituting elements serving as its core values: freedom of choice and focus on speaker's linguistic personality.

Freedom of choice is manifested by stating open borders for those that incorporate the duplicated code, which is why repetition is a vital necessity, e. g.:

(20) Could you please, Pleaseeeeeeeeee repeat

As we see in 3.2, translated repetitions are not so common as untranslated ones. It is likely that Nuyorican Spanglish speakers being fluent in both substrate languages do not need to differenciate between them as they constantly switch their elements, thus mixing them, e. g.:

(21) Even the Spanish people that came with Colon, Columbus

However you want to say it

This makes Spanglish the key to open doors that are closed for monolingual speakers, e. g.:

(22) - Ábrela tú. adentro.

— ¿Por qué yo? Tú tienes las keys. Yo te las entregué a ti. Además, I left mine

- ¿Por qué las dejaste adentro?

- Porque I knew you had yours.

- ¿Por qué dependes de mí?

- Just open it, and make it fast. Y lo peor de todo es cuando te levantas por las mañanas y te vas de la casa y dejas la puerta abierta $<\ldots>$ Alguien puede entrar y robarme y violarme. Y tú tan Pancho, Sancho, ni te importa.

(23) My Nuyorican Puerta opened on that Friday night. Elegua gave me permission to walk through - and I did.

This key in the form of code-switching can also close, i.e. protect people from aggression and violence, e. g.:

(24) If I had another room, if I could close myself away from you...

Finally, freedom of choice, being an attribute of democracy, makes it possible for Spanglish speakers to stand up and have their say. In doing so, they take up the modernist 'waiting for Godot' principle. The difference is that they are never happy with that waiting in vain makes them angry, and thye realize that change is also quite a relative thing. So this situation gets a new interpretation: Spanglish speakers have created their own identity, but it is an error to think that it is enough to change yoursleft. As long as you stay in bed and do not manifest your ideas to the world, nothing will really change, no matter how many times you repeat your words, e. g.:

(25) The problem comes when I realize I have done nothing and I'm still in bed rocking - waiting for Godot or a change of climate. I get so angry at myself that I stand up and write my rage and feel good again and I change, and I change, and I change, but I never really change.

(26) For is it Mother that gives birth to change. The alpha and the omega, the yin and the yang of Nuyorican words would be born to bring the world a new poetic justice

that would define a generation.

The concept of error and fallacy is approached in a new way. An error in the use of a particular linguistic unit ceases to be the object of criticism. On the contrary, it turns into a marker of confusing linguistic codes that complicate the context. In the same way, the author approaches the freer use of punctuation marks. The period and comma in her novel receive a philosophical content: the period is a symbol of certainty, strict order, while the 
comma is uncertainty as an opportunity to choose one's own destiny, creative independence. In this context, the social hierarchy and the place of the individual in it lose their importance. Duplication of structures can be multi-layered.

For example, on the one hand, 'Yo' can be seen as an allusion to Julia Alvarez's novel $Y o$, which in turn is a truncated name for the main character (Yolanda). On the other hand, 'yo' is the Spanish personal pronoun of the 1st person singular. Finally, 'yo' doubles and becomes 'yo-yo', which also has a double meaning, namely:

1) literal stuttering as a speech characteristic of one of the characters;

2) stuttering as a metaphor for doubling the linguistic personality, which is realized in one of the key moments of the novel, when 'yo-yo' actually becomes the answer to the question about the place of a Hispanic person in the American society. This idea is not only illustrated in example (27) below, but also is the popular spelling of the word 'NuYoRican' used in mass media to state that the linguistic personality is the principal value so much protected by Spanglish:

(27) - Ya know - he pointed at you - ya know wha-what you are?

- Me? - You shrugged shyly.

- Ya, ya know wha-what you are?

-Wha-what?

- You're a, you're a pentagram - then he pointed at me — and you, ya know wha-what you are?

$<\ldots>$

-Ya know wha-what you are? - he sta-stammered - You're a, you're a

Yo-Yo. ;Boing!

In example (27), the double encoding of the contaminated 'ya' - the Spanish adverb 'ya' ('already') and the reduced form of the English personal pronoun 'you' — creates another level of meaning in this example: 'Ya know' ('You know' or 'Already you know').

Both core values stated above eventually create the pride of belonging to this duplicated Nuyorican Spanglish world, as seen in the great triade based on creativity in the following example.

(28) The Spirit of Pride emerged in art.

The Spirit of Self emerged in art.

The Spirit of Open Doors emerged in art.

Out these philosophical components, 'the Spirit of Self'can be considered the central one, as it reflect how much Nuyricans suffers from conflict and contradiction, being torn between two codes, e.g.:

(29) This is my story

A tale of two cultures

Two countries, two languages

One idenity, one nuyorican

One me

According to Noel Quiñones, a poet and philosopher of Nuyorican culture, the only way to overcome this conflict is to use Spanglish - the language you 'can never learn', the language that you 'feel within' you. Thus, the metaphor 'Yo' in example (27) can be extended to denote not only the speaker of this tongue, but also the generalized space where Spanglish structures manifest themselves through code-switching.

\section{Conclusions}

Direct and contaminated double encoding of language units is implemented in the repetition technique. It creates a vibrating fabric of narrative, combining prose, poetry, dramatic fragments. The technique helps to decipher a new code at the linguistic level: repetition as a 
physical resonance - duplication of meanings, which leads to increased accents. At the same time, Nuyorican Spanglish writers and poets philosophize about the nature of such a linguistic echo and come to the conclusion that it is primary and primordial; it is exactly what prevents the excessive stability of the language and stimulates its dynamic development.

Thus, the technique of repetition performs an auxiliary function to the whole codeswitching strategy: it exhibits the complex architectonics of the text created by switching and mixing the language code. This is a linguistic analogue of a chemical reagent, with the help of which Nuyorican Spanglish speakers explore socio-political and economic prospects for a Hispanic bilingual in the United States. In this, they resort to a paradox. It turns out that it's good not to know your place in culture - this gives you freedom of choice, and it is real democracy. Here the opposition of officialdom and real life, English and Spanish, finds expression. In such a situation, Spanglish demonstrates the dialectical unity and struggle of two opposites. Foreign language labeling in Spanglish does not serve the purpose of assimilation and stabilization, which can negatively affect the state of the language and society. On the contrary, it creates the necessary dynamics and versatility, stimulates the search for non-standard (or, rather, post-standard) solutions, which are also the most efficient ones, and opens up new horizons in linguistic and philosophical contexts.

\section{References}

1. Jeff MacSwan, Grammatical Theory and Bilingual Codeswitching (2014).

2. Daniel Schreier, Marianne Hundt, Edgar W. Schneider, The Cambridge Handbook of World Englishes (2020).

3. Harriet Okoh, Studies in English Language Teaching 7, 174-194 (2019). doi: 10.22158/selt.v7n2p174.

4. Ilan Stavans, The United States of Mestizo (2013).

5. Ana Celia Zentella, Keywords for Latino Studies, 209-212 (2017).

6. Ana Celia Zentella, Spanish-English Codeswitching in the Caribbean and the US, 1135 (2016).

7. Ana Celia Zentella, Language and Social Justice in Practice, 217-225 (2018).

8. Daniel T. Lichter, Domenico Parisi, Michael C. Taquino, Rural Sociology 81 (4), 483518 (2016). doi: 10.1111/ruso.12108.

9. Eugenia Casielles-Suárez, Atlantis 39 (2), 147-168 (2017). doi: 10.28914/Atlantis2017-39.2.08.

10. Silvia Betti, El inglés y el español en contacto en los estados unidos reflexiones acerca de los retos, dilemas y complejidad de la situación sociolingüística estadounidense, 1148 (2020).

11. Cecilia Montes-Alcalá, Spanish-English Codeswitching in the Caribbean and the US, 191-213 (2016).

12. Ángel López García-Molins, Teoría del Spanglish (2015).

13. Silvia Betti, Glosas 5 (14) (2015).

14. Naomi Lapidus Shin, Ricardo Otheguy, Language in Society 42 (4), 429-452 (2013). doi: 10.1017/S0047404513000468.

15. Cecilia Montes-Alcalá, Journal of Language Contact 9 (1), 23-48 (2016). doi: 10.1163/19552629-00901002. 